\title{
Model of Highland Vegetables Farming Based on Local Wisdom
}

\author{
Pujiharto \\ Universitas Muhammadiyah Purwokerto \\ pujiharto@ump.ac.id
}

\begin{abstract}
The purpose of this research is to present a model of highland vegetable farming based on local wisdom. The research was conducted purposively on the Upper Serayu River Basin covering two districts, namely Banjarnegara and Wonosobo. The quantitative and qualitative data were analyzed descriptively. The results indicate that the farmers play important roles based on the local wisdom, including returning plant residues into the soil (recycling), using organic fertilizers, implementing crop rotations, implementing optimum water management, using specific environmental varieties, conducting pest and disease control with IPM principles, using anorganic fertilizers, making terraces on slopes, and planting avocation resistant crops. The model of highland vegetable farming based on local wisdom is influenced by uncontrollable and controlled factors, such as macro climate condition (rainfall) and socio-economic of farmers as well as farm management. The model will generate desired outputs and undesired outputs; both outputs affect the local advantages.
\end{abstract}

Keywords: model of highland vegetable farming, local wisdom, uncontroled and controled factors, desired and undesired output..

\section{INTRODUCTION}

Humans have a unique relationship with the environment because it shapes their behavior in a population, changing the pattern of human adaptation by forming its social system [1]. This constantly changing pattern of interaction will ultimately shape cultural specialization; one of which is the peculiarity in cultivation. A cultivation method supported by appropriate agro-ecological physical condition it will form competitive commodity farming. The competitiveness, as reflected by competitive advantages and comparative advantages of a commodity, reflects the most prevalent condition in Indonesia, that is the lack of farmers' awareness [2]. The phenomenon of environmental changes due to changes in temperature, weather, and rainfall has caused the decrease in productivity and income of farmers. This symptom is generally complex and involves many natural factors so that its presence is often not easily detected early [3]. Consequently, it often results in large losses due to the lack of anticipatory actions that can be prepared in advance. If there is no effort to improve the capacity of farmers, this situation might threaten the national food security due to crop failure related to environmental changes in the environment [4]

Local wisdom is part of human behavior related to the natural environment which can be derived from religious values, customs, ancestors or local cultures [5]. It is naturally and socially constructed in a community in order to adapt to the surrounding environment. On the other hand, ongoing environmental changes and their effects cannot be avoided. Therefore, efforts should be make to anticipate negative impacts that may occur by utilizing the local advantages of the region. The description shows how important it is to conduct research on highland vegetable farming based on local wisdom and local advantages in an effort to cope with environmental changes.

\section{METHOD}

Research sites along the Serayu River Basin cover two districts of Wonosobo and Banjarnegara. Samples were taken by random sampling method. The number of respondents is 60 farmers who grow highland vegetables around the watershed. The type of data in this research is primary data obtained from observations and interviews using a questionnaire. Local wisdom is analyzed descriptively, indicating the potential of local wisdom that can be applied by farmers around the upper Serayu watershed [6]

Research stage to obtain model of farm based on local wisdom Stage I: Identification of farming patterns and local wisdom. Stage II: Formulation and Preparation of Local Wisdom Farming Model. Stage III: Trial of Local Wisdom-Based Farming Model. Stage IV: Implementation of Local Wisdom-Based Farming Model. [7]

\section{RESULT}

The local wisdom of farmers in highland vegetable farming in the research area is presented in Table 1. The indicator consists of 9 actions. 
Table 1. The Role of Farmers According to Local Wisdom

Indicators in the Upper Serayu Basin.

\begin{tabular}{clccc}
\hline No & Action & $\begin{array}{c}\text { Number of } \\
\text { Respondent } \\
\text { s Acting } \\
\text { (Person) }\end{array}$ & $\begin{array}{c}\text { Number of } \\
\text { Respondent } \\
\text { s } \\
\text { (People) }\end{array}$ & $\begin{array}{c}\text { Percen } \\
\text { t } \\
(\%)\end{array}$ \\
\hline 1. & A & 49 & 60 & 81.67 \\
2. & B & 58 & 60 & 96.67 \\
3. & C & 38 & 60 & 63.33 \\
4. & D & 21 & 60 & 35.00 \\
5. & E & 36 & 60 & 60.00 \\
6. & F & 18 & 60 & 30.00 \\
7. & G & 37 & 60 & 61.67 \\
8. & H & 41 & 60 & 68.33 \\
9. & I & 32 & 60 & 53.33 \\
\hline S6urce
\end{tabular}

Source: Processed Primary Data, 2017

Note:

A $\quad=$ The return of plant residues into the soil (recycle).

$\mathrm{B} \quad=$ Use of organic fertilizer

$\mathrm{C}=$ Crop rotation / varieties

$\mathrm{D}=$ Optimum water management

$\mathrm{E}=$ Use of adaptive specific environmentally superior

$\mathrm{F}=$ Control of pests and diseases with the principle of

IPM

$\mathrm{G}=$ = Use of inorganic fertilizers on a balanced basis

$\mathrm{H} \quad=$ Making of terracing on slope field

I $\quad=$ Planting of landslide resistant crops

The first is returning plant residues to the soil (recycle). As many as 81.67 percent of the farmers returned the rest of the harvest to the land; how to immerse the rest of the harvest coincided with the time of processing the land. The remaining crops serve as organic fertilizers that can increase soil fertility besides manure, especially from chicken manure mixed with rice husk. They can also suppress weed growth, facilitate fertilizer or mixing of fertilizer, granular insecticide, and increase soil nutrient availability for plants [8]. The reason of the farmers to take the action of returning plant residues to the soil (recycle) is the high price of agricultural production facilities, especially artificial fertilizers, the awareness to maintain the sustainability of land productivity using natural ingredients that exist around the farmers.

The second action is the use of organic fertilizer. Highland vegetable farmers in the study sites have utilized natural ingredients such as manure, compost, and the leave of lamtoro to maintain and improve the fertility of the land. Provision of organic materials is done after the processing of the land. Most of the farmers used organic fertilizers as the main fertilizer in Highland vegetable farming. Some only rely on the use of inorganic fertilizers such as urea, ZA, SP36, NPK [9]

The respondent farmers who carried out the third action, crop rotation, were 63.33 percent. Crop rotation is important to maintain soil fertility. Different plants will absorb different nutrients in number and kinds. On this basis, farmers cultivating highland vegetables do crop rotation or rotation varieties [10]
The fourth action is implementing optimum water management. Water is one of important environmental factors for achieving the growth and development of highland vegetables. The use of water for short periods especially in the growth phase is very useful, particularly for reducing toxic compounds or gases [11] . Lack of water at a particular moment, especially at the time of growth, can lead to decreased production even failure. Conversely, the provision of too much water, in addition to disturbing, is also a waste of water. Respondents farmed to dig wells to irrigate cultivated crops. As many as 35 percents of the farmers used optimum water management.

With regard to the fifth action, 60 percent of farmers used adaptive varieties of specific environmental variables while 40 percent of farmers used local varieties. Each variety has its own advantages related to the environment/location of planting. The reason why farmers used the local varieties is because the price is cheap, for example potato varieties i.e. atlantic varieties [4]. The sixth action is pest and disease control with IPM (Integrated Pest Management) principle. A total of 30 farmers in the study sites had known and applied IPM. IPM control in addition to being economically profitable is socially harmless to human health. It also ecologically provides a balance of ecosystems. With regard to the balance of the ecosystem, it was revealed by the respondents that some indicators indicate the restoration of ecosystem balance; many earthworms and microorganisms were found on their land. In addition, in an integrated pest control effort, farmers have managed to find the ingredients to control the pests formulated from natural ingredients: dadap leaf, kelor leaf, gliricidae leaf and lamtorogung leaf. [12]

The seventh action, the use of inorganic fertilizers in a balanced manner. As many as 61.67 percent of farmers respondents do this action. The fertilizers used are urea, ZA, SP36, and NPK. In coordination of counseling program has been agreed together that the need for balanced fertilization with strict guidance with the dose of fertilizer according to the cultivated crop. Farmers' responses to balanced fertilization vary, so fertilizer application also varies. Some farmers do fertilization with aSingle fertilizer on the grounds that the price of inorganic fertilizers is quite expensive. For farmers with a low economic condition, they are not willing to pay for the fertilizer [13].

The eighth action is the making of terraces on the slopes. A total of 68.33 percent of the farmers make terracing on Highland vegetable farming. There are 2 kinds of terraces in the research area, which are permanent and nonpermanent terrace . The permanent terraces are made of stones laid out so that they resemble a porch bench and are resistant to landslides. Meanwhile, the terrace is not permanent; it is only made of ordinary soil that easily slides. Terraces often found in the study area of the bench terrace are not permanent with the bands perpendicular to the slope of the land. For the most frequent potato farming with the slope of the land, it is intended to facilitate the dispose of water in the rainy 
season so that the plants do not rot because of waterlogged [14]

The ninth act is the planting of landslide resistant crops. Landslide retention plants are usually annual crops such as lamtoro, dadap, and albasia. As many as 53.33 percents of farmers do this action, while the rest do planting border plants just to dispel pest attacks and plant diseases. Border plants are planted around the edge of the land as the main crop protective plants. [4]

Model of Highland Vegetablee Farming based on local wisdom

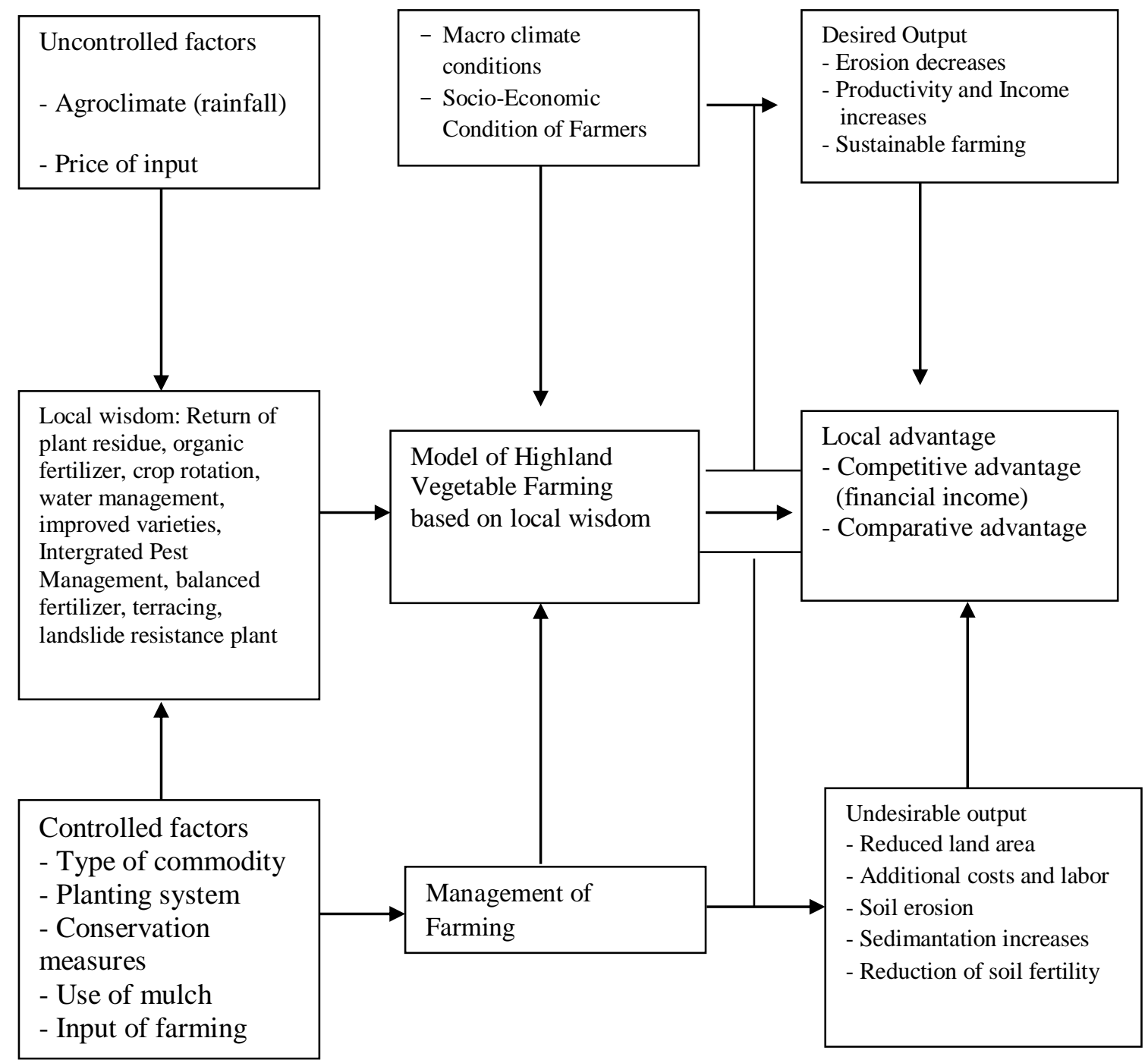

Figure 1. Model of Highland Vegetable Farming Based on Local Wisdom

The model of highland vegetable farming based on local wisdom is strongly influenced by uncontrollable and controlled factors. These factors influence the local wisdom behavior of farmers. The factors of macro climate condition (rainfall) and socio-economic of farmers and farm management factor have an effect on the model of highland vegetable farming, whereas the farming will yield desired output and undesired output. Both outputs will affect the local advantage. Land slide resistant crops. The model of highland vegetable farming based on local wisdom will yield desired output and undesired output. Both outputs will affect the local advantage

\section{CONCLUSION}

The role of farmers based on Local Wisdom in the Upper Serayu Basin includes returning plant residues into the soil (recycling), using organic fertilizers, doing crop rotation/varieties, using optimum water management, using adaptive varieties of specific environmental varieties, implementing pest and disease control with IPM principles, using balanced inorganic fertilizers, on slopes and planting 


\section{REFERENCES}

[1] V. R. Vitasurya, "Local Wisdom for Sustainable Development of Rural Tourism, Case on Kalibiru and Lopati Village, Province of Daerah Istimewa Yogyakarta," Procedia - Soc. Behav. Sci., vol. 216, no. October 2015, pp. 97-108, 2016.

[2] R. E. Rahayu, Analisis kelembagaan dan Strategi PeningkatanDaya Saing Komoditas Kentang ( Solanum tuberosum L .) Di Kabupaten Karo, Sumatera Utara. 2015.

[3] Y. Athanasius Aditya Wisnu Graha, "Potret Kearifan Lokal Perubahan Iklim dan Pengaruhnya Terhadap Produktivitas Padi Sawah Di Salatiga," vol. 27, no. 1, pp. 50-59, 2015.

[4] Pujiharto, "Productivity and Productivity Risk of Potato Farming in Banjarnegara Regensi," vol. XV, no. 2, pp. 1-13, 2013.

[5] N. Iriani, W. Agustim, and T. Sasongko., "the Development of Potential Creative Economy Based on Local Wisdom in Dealing With Global Challenges.," Int. J. Adv. Res., vol. 4, no. 11, pp. 2180-2186, 2016.

[6] Z. Zaidah and Z. Zainal, "Case study as a research method," J. Kemanus., vol. 9, no. Journal Article, pp. 1-6, 2007.

[7] W. Spencer, L., Ritchie, J. \& O’Connor, QUALITATIVE A Guide for. 2003.

[8] J. V. N. S. Prasad et al., "Effect of ten years of reduced tillage and recycling of organic matter on crop yields, soil organic carbon and its fractions in Alfisols of semi arid tropics of southern India," Soil Tillage Res., vol. 156, no. November 2015, pp. 131-139, 2016.

[9] J. Lumbanraja, C. P. Satgada, M. Utomo, and R. Hasibuan, "Phosphorus ( $\mathrm{P}$ ) Adsorption Behavior and Harvested $\mathrm{P}$ by the Sugarcane ( Saccharum officinarum L .) Affected by Inorganic and Organic Fertilizer Applications on an Ultisol Phosphorus ( P ) Adsorption Behavior and Harvested P by the Sugar- cane ( Saccharum ," no. April, 2018.

[10] G. Kim and T. Mark, "Incorporating New Crops into Traditional Crop Rotation and the Environmental Implication By," pp. 1-22, 2017.

[11] K. P. S. T. Pathirana, R. M. A. D. S. Thanapathy, and K. D. W. Nandalal, "River Basin Modelling for Optimum Water Usage: Uma Oya Downstream Development Area," Inst. Eng., vol. L, no. 02, pp. 11-20, 2017.

[12] C. Paper et al., "Best Practices for the Use and Exchange of Invertebrate Biological Control Agents," 2017, no. November.

[13] E. Solgi, H. Sheikhzadeh, and M. Solgi, "Role of irrigation water, inorganic and organic fertilizers in soil and crop contamination by potentially hazardous elements in intensive farming systems: Case study from Moghan agro-industry, Iran," J. Geochemical Explor., vol. 185, no. February, pp. 74-80, 2018.

[14] Q. xue Xu et al., "The effects of rainfall regimes and terracing on runoff and erosion in the Three Gorges area, China," Environ. Sci. Pollut. Res., vol. 25, no. 10, pp. 9474-9484, 2018. 